Archives of Agriculture and Environmental Science

\title{
Influence of weeding regime on the performance of aromatic Boro rice (Oryza sativa L.)
}

\author{
Swapan Kumar Paul ${ }^{*}$ (D) , Layla Sabequn Nahar, Newton Chandra Paul and Mahfuza Begum \\ Department of Agronomy, Bangladesh Agricultural University, Mymensingh-2202, BANGLADESH \\ "Corresponding author's E-mail: skpaul@bau.edu.bd
}

\section{ARTICLE HISTORY}

Received: 18 March 2019

Revised received: 05 May 2019

Accepted: 18 May 2019

\section{Keywords}

BRRI dhan50

Crop characters

Crop yield

Herbicides

Weeding regime

\section{ABSTRACT}

An experiment was conducted at the Agronomy Field Laboratory, Bangladesh Agricultural University, Mymensingh, from December 2013 to May 2014 to investigate the influence of weeding regime on the performance of aromatic Boro rice (cv. BRRI dhan50). The experiment comprised nine treatments viz., un-weeded, one hand weeding at 20 DAT + pre-emergence herbicide after hand weeding, two hand weeding at 20 and 40 DAT, pre-emergence herbicide followed by one hand weeding at 20 DAT, pre-emergence herbicide followed by one hand weeding at $40 \mathrm{DAT}$, post-emergence herbicide + one hand weeding at $40 \mathrm{DAT}$, pre-emergence herbicide + post-emergence herbicide, pre-emergence herbicide + post-emergence herbicide + one hand weeding at 40 DAT and weed free throughout the growth period. Panida (pendimethalin) @ $2.5 \mathrm{~L} \mathrm{ha}^{-1}$ as pre-emergence herbicide and granite (penoxsulam) @ $93.70 \mathrm{ml}$ $\mathrm{ha}^{-1}$ as post-emergence were used for weed control. The experiment was laid out in a randomized complete block design with four replications. Thirteen weed species belonging to seven families were observed in the experimental field. The highest weed density and dry weight were observed in no weeding condition compared to other treatments. The tallest plant, the highest number of total tillers hill $^{-1}$, number of effective tillers hill ${ }^{-1}$, total spikelets panicle ${ }^{-1}$, grains panicle ${ }^{-1}, 1000^{-}$grain weight, grain yield, straw yield, biological yield and harvest index were obtained from weed free treatment. The highest grain yield $\left(5.92 \mathrm{t} \mathrm{ha}^{-1}\right)$ was obtained from weed free throughout the growth period. Grain yield was reduced by $56.42 \%$ due to weed infestation in unweeded condition. The highest benefit-cost ratio (2.28) was obtained from application of pre-emergence herbicide followed by post-emergence herbicide + one hand weeding at 40 DAT. Therefore, weeding treatment pre-emergence herbicide followed by post-emergence herbicide + one hand weeding at 40 DAT may consider for cultivation of aromatic Boro rice (cv. BRRI dhan50).

(C)2019 Agriculture and Environmental Science Academy

Citation of this article: Paul, S.K., Nahar, L.S., Paul, N.C. and Begum, M. (2019). Influence of weeding regime on the performance of aromatic Boro rice (Oryza sativa L.). Archives of Agriculture and Environmental Science, 4(2): 133-140, https://dx.doi.org/10.26832/24566632.2019.040202

\section{INTRODUCTION}

Rice (Oryza sativa L) is the staple food for the people of Bangladesh. Aromatic rice is special group that covers $2 \%$ of the national rice acreage of Bangladesh and $12.5 \%$ of the total transplant Aman rice cultivation (Roy et al., 2018). Most of the aromatic rice varieties are traditional photo-period sensitive type and grown during Aman season in Bangladesh (Kabir et al., 2004). The average yield of rice in Bangladesh is $3.04 \mathrm{t} \mathrm{ha}^{-1}$ and which is very much lower than world average (Sinha et al., 2018).
Islam et al. (1996) noticed that the yield of aromatic rice was lower (1.5-2.0 $\mathrm{t} \mathrm{ha}^{-1}$ ) but its higher price and low cost of cultivation generated higher profit margins compared to other varieties grown in the area. Bangladesh Rice Research Institute (BRRI) developed a modern aromatic rice BRRI dhan50 (Banglamoti) with high yield ability which is suitable for Boro season.

Severe weed infestation reduces the grain yield in Aus, Aman and Boro season in $70.80 \%, 30-40 \%$ and $22-36 \%$ in Bangladesh (Sarkar et al., 2017). In case of aromatic rice grain 
yield reduced by $59.82 \%$ for BRRI dhan 50 in Boro season (Sinha et al., 2018) and 28.16\% for Binadhan-9 in Aman season (Zannat et al., 2014). The traditional method of weed control is hand weeding which is very much laborious and time consuming. Mechanical weeding and herbicides are the alternative to hand weeding. Herbicides are effective in controlling weeds alone or in combination with hand weeding (Ahmed et al., 2005). Herbicides in combination with hand weeding would help to obtain higher crop yield with less efforts and cost (Sathyamoorthy et al., 2004). Weed competition at early growth stage can be eliminated through pre-emergence herbicides like Panida, Ronstar 25 EC and Rifit 50 EC and post emergence herbicides Granaite and 2, 4-D amine. This type of herbicides can be used in Bangladesh against mono and dicotyledonous weeds in rice fields. Replacement of traditional weeding in Boro rice by pre-emergence and post-emergence herbicides or herbicides in combination with hand weeding would help obtain higher rice yield. Therefore, the present study was undertaken to determine the effective weed control option for maximizing yield of BRRI dhan 50 .

\section{MATERIALS AND METHODS}

\section{Experimental design}

The experiment was conducted at the Agronomy Field Laboratory, Bangladesh Agricultural University, Mymensingh, during the period from December 2013 to May 2014. The experimental site is located at $24.75^{\circ} \mathrm{N}$ latitude and $90.50^{\circ} \mathrm{E}$ longitude at an elevation of $18 \mathrm{~m}$ above the sea level. The site belongs to the non-calcareous dark grey floodplain soil under the Agro-ecological Zone of the Old Brahmaputra Floodplain (AEZ-9) (UNDP and FAO, 1988). The soil of the experimental field belongs to the Sonatala soil series which is slightly acidic in reaction with $1.29 \%$ organic matter content. The experimental field was a medium high having $\mathrm{pH}$ 6.5. The experiment consisted of nine treatments viz. Unweeded $\left(\mathrm{T}_{1}\right)$, One hand weeding at 20 days after transplanting (DAT) + pre-emergence herbicide after hand weeding $\left(\mathrm{T}_{2}\right)$, Two hand weeding at 20 and 40 DAT $\left(\mathrm{T}_{3}\right)$, Pre-emergence herbicide followed by one hand weeding at 20 DAT $\left(\mathrm{T}_{4}\right)$, Pre-emergence herbicide followed by one hand weeding at 40 DAT $\left(T_{5}\right)$, Post-emergence herbicide + one hand weeding at 40 DAT $\left(T_{6}\right)$, Pre-emergence herbicide + postemergence herbicide $\left(T_{7}\right)$, Pre-emergence herbicide + postemergence herbicide + one hand weeding at $40 \mathrm{DAT}\left(\mathrm{T}_{8}\right)$ and Weed free throughout the growth period $\left(T_{9}\right)$. The experiment was laid out in a one factor randomized complete block design with four replications. The size of a unit plot was $4.0 \mathrm{~m} \times 2.5 \mathrm{~m}$ $\left(10 \mathrm{~m}^{2}\right)$. The spacing between the unit plots was $50 \mathrm{~cm}$ and that between the blocks was $1.0 \mathrm{~m}$.

\section{Description of herbicides}

A short description of herbicides that were used in the experiment is given in the Table 1.

Healthy seeds were selected by specific gravity method. Seeds were then immersed in water in bucket for 24 hours. Then seeds were taken out of water and kept thickly in gunny bags. The seeds started sprouting after 48 hours and were sown after 72 hours on 1 December, 2013 with proper care. The land was first opened with a tractor drawn disc plough on 29 December, 2013. The land was then puddled thoroughly by repeated ploughing and cross ploughing with a country plough and subsequently leveled by laddering. The field layout was made on 8 January, 2014 according to experimental specification immediately after final land preparation. Weeds and stubbles were cleared off from individual plots and finally plots were leveled properly by wooden plank so that no water pocket could remain in the field. The land was fertilized with urea, triple super phosphate, muriate of potash, gypsum, zinc sulphate @ 250 kg, 120 kg, 120 $\mathrm{kg}, 100 \mathrm{~kg}, 10 \mathrm{~kg} \mathrm{ha}^{-1}$, respectively. The whole amount of triple super phosphate, muriate of potash, gypsum, zinc sulphate were applied at the time of final land preparation. Urea was applied in 3 equal split at 10, 30 and 45 DAT. Seedlings were transplanted on 9 January, 2014 using two seedlings hill ${ }^{-1}$ with $25 \mathrm{~cm} \times 15 \mathrm{~cm}$ spacing between the rows and hills, respectively. The gaps were filled up with the seedlings from the same source. Weeding was done as per experimental specification. Flood irrigation was given to maintain a level of standing water up to $2-4 \mathrm{~cm}$ till maximum tillering stage and after that, a water level of $7-10 \mathrm{~cm}$ was maintained up to grain filling stage and then drained out after milk stage to enhance maturity. The crop was attacked by yellow rice stem borer (Scirpopaga incertulas) at the panicle initiation stage which was successfully controlled with Sumithion @ $1.5 \mathrm{~L}$ $\mathrm{ha}^{-1}$. Four hills were randomly selected from each plot (excluding boarder rows and central $1 \mathrm{~m}^{2}$ ) and uprooted to record data on crop characters and yield components. After sampling, the whole plot was harvested on 7 May, 2014 when $90 \%$ of the seeds became golden yellow in colour. At maturity, one square meter area from each plot was selected from the central portion and was cut manually from the ground level to take grain and straw yields. The harvested crop of each plot was separately bundled, properly tagged and then brought to the threshing floor. The harvested crops were threshed manually. The grain was cleaned and dried to a moisture content of $14 \%$. Straws were sun dried properly. Final grain and straw yields plot $^{-1}$ were recorded and converted to $\mathrm{tha}^{-1}$. Harvest index was calculated using the following formula.

$$
\text { Harvest index }(\%)=\frac{\text { Grain yield }}{\text { Biological yield }} \times 100
$$

Table 1. Short description of herbicides that were used in the experiment.

\begin{tabular}{lllll}
\hline Trade name & Common name & Mode of action & Selectivity & Time of application \\
\hline Panida 33 EC & Pendimethalin & Systematic & Selective for potato and rice & Pre-emergence (3 DAT) \\
Granite 240 SC & Penoxulam & Systematic & Selective for rice & Post-emergence (12 DAT) \\
\hline
\end{tabular}




\section{Weed parameter}

The $1^{\text {st }}$ data on weed infestation was taken from the plots where $T_{2}, T_{3}$ and $T_{4}$ treatments were applied at 20 DAT of rice plant. The $2^{\text {nd }}$ data on weed infestation was taken from the plots where $T_{3}, T_{5}, T_{6}$ and $T_{8}$ treatments were applied at 40 DAT of rice plant. The $3^{\text {rd }}$ data on weed infestation was taken from each of the unit plot as per treatments at dough stage of rice plant. The data were taken by $0.25 \mathrm{~m}^{2}$ quadrate from two places of each plot at random.

The weeds infested in each plot were identified species-wise and their density per square meter was counted. The density of weed was determined using a quadrate of $0.25 \mathrm{~m}^{2}$ in two places at random in each plot. The average number of two samples was converted to no. $\mathrm{m}^{-2}$. The weeds inside each quadrate for density count were uprooted, cleaned and separated. The collected weeds were dried in an electrical oven for 72 hours maintaining a constant temperature of $80^{\circ} \mathrm{C}$. After drying, weight of dried weeds were taken and converted to $\mathrm{g} \mathrm{m}^{-2}$. The plants at dough stage inside quadrate $\left(0.25 \mathrm{~m}^{2}\right)$ were uprooted. The roots of each plant were removed. Then the plants were washed with tap water and the plant samples were packed in labeled brown paper bags and dried in the oven at $85 \pm 5^{\circ} \mathrm{C}$ for 72 hours until constant weight was reached. The dried samples were weighed carefully and converted to $\mathrm{tha}^{-1}$.

\section{Statistical analysis}

The recorded data were compiled and subjected to statistical analysis. Analysis of variance was done following randomized complete block design with the of computer package MSTAT. The mean differences among the weed control treatments were adjudged by Duncan's New Multiple Range Test (Gomez and Gomez, 1984).

\section{RESULTS AND DISCUSSION}

Infested weed species in the experimental field

Thirteen weed species infested the experimental field which belongs to seven families. Among these species 5 belonged to
Gramineae, 3 Cyperaceae, 2 Pontederiaceae and 1 from Oxalidaceae, Araceae. The most important weed in the experimental plots were Scirpus juncoides, Echinochloa crusgalli and Monochoria hastata. Weeds grown in the experimental plot were grass, broad-leaved, sedge type. The particulars of weeds common name, english name, scientific name, family name and life cycle have been presented in Table 2 .

\section{Effect of weed control treatments on weed density}

Weed density was influenced by different weed control treatments as recorded at 20 DAT, 40 DAT and at harvest of the rice plot (Table 3 and 4). The highest weed density was observed in the unweeded treatment and the lowest weed density was observed at weed free treatment. This result is agreement with the findings of Rekha et al. (2002). The weed population at harvest was higher than that of the population at 20 DAT and 40 DAT. Scirpus juncoides, Echinochloa crusgalli and Monochoria hastate were the most important weeds in experimental plot. Among these Echinochloa crusgalli, Monochoria hastate were significantly controlled by pre-emergence herbicide + postemergence herbicide + one hand weeding at 40 DAT. But the infestation of Scirpus juncoides was so high that no control measures were effective to control this weed species.

\section{Effect of weed control treatment on weed dry weight}

Weed dry weight was influenced by weed control treatment (Table 5). The highest weed dry weight (183.14 $\mathrm{g} \mathrm{m}^{-2}$ ) was observed in the unweeded treatment and the zero dry weight of weed was observed at weed free treatment. This result is agreement with the findings of Jena et al. (2002). It was also foundthat the pre-emergence herbicide and post-emergence herbicides when supplemented with one hand weeding at 40 DAT gave lower dry weight $\left(34.76 \mathrm{~g} \mathrm{~m}^{-2}\right)$ of weed and pre-emergence herbicide when supplemented with one hand weeding at 40 DAT gave lower dry weight $\left(35.71 \mathrm{~g} \mathrm{~m}^{-2}\right)$ of weed were more effective than other weed control treatments. The weed population at harvest was higher than that of the population at 20 DAT and 40 DAT.

Table 2. List of weed species in the experimental field.

\begin{tabular}{lllll}
\hline Common Name & English name & Scientific name & Family name & Life cycle \\
\hline Panikachu & Pickerel weed & Monochoria vaginalis (Burm. f.) Presl. & Pontederiaceae & Perennial \\
Holde mutha & Yellow nutsedge & Cyperus esculentus L. & Cyperraceae & Perennial \\
Angta & Torpedo grass & Panicum repens L. & Gramineae & Perennial \\
Bara Shama & Barnyard grass & Echinochloa crusgalli L. Beauv. & Gramineae & Annual \\
Arail & Swamp rice grass & Leersia hexandra Sw. & Gramineae & Perennial \\
Joina & Globe fringerush & Fimbristylis milliaceae L. Vahl & Cyperaceae & Annual \\
Chesra & Bulrush & Scirpus juncoides Roxb. & Cyperacea Annual & Annual \\
Amrul & Yellow wood sorrel & Oxalis europaea Jord. & Oxalidaceae & Annual \\
Chela ghash & Curved sickle grass & Parapholis incurva (L.) C.E. Hubb & Gramineae & Perennial \\
Topapana & Water lettuce & Pistia stratiotes Var. & Araceae & Annual \\
Anguli ghash & Crab grass & Digitaria sanguinalis L. Scop. & Verbenaceae & Annual \\
Motka & Bushy matgrass & Lippia germinata H.B.K. & Pontederiaceae & Perennial \\
Kachuripana & Water hyacinth & Eichhornia crassipes (Mart.) Solms & Poe &
\end{tabular}


Table 3. Weed density (no. $\mathrm{m}^{-2}$ ) at 20 DAT and 40 DAT.

\begin{tabular}{|c|c|c|c|c|c|c|c|}
\hline \multirow{2}{*}{ Weed Species } & \multicolumn{3}{|c|}{ At 20 DAT } & \multicolumn{4}{|c|}{ At 40 DAT } \\
\hline & $\mathrm{T}_{2}$ & $T_{3}$ & $\mathrm{~T}_{4}$ & $\mathrm{~T}_{3}$ & $T_{5}$ & $T_{6}$ & $\mathrm{~T}_{8}$ \\
\hline Echinochloa crusgalli L. Beauv & 65.00 & 38.00 & 3.00 & 44.00 & - & 17.00 & 143.50 \\
\hline Scirpus juncoides Roxb. & 36.50 & 23.00 & 34.50 & 82.75 & 8.25 & 5.00 & - \\
\hline Monochoria hastate L. & - & - & 0.50 & 4.00 & - & - & - \\
\hline Panicum repens L. & 3.00 & 5.00 & 4.50 & - & 10.50 & 4.50 & 2.50 \\
\hline Leersia hexandra Sw. & - & - & - & - & 0.50 & - & - \\
\hline Oxalis europaea Jord. & 1.50 & - & - & - & - & 0.50 & - \\
\hline Pistia stratiotes Var. & 1.50 & 2.50 & 1.50 & - & - & - & - \\
\hline Digitaria sanguinalis L. & 0.50 & 0.50 & 0.50 & - & - & - & - \\
\hline
\end{tabular}

Treatments: $T_{1}$ : Unweeded, $T_{2}$ : One hand weeding at 20 DAT + pre-emergence herbicide after hand weeding, $T_{3}:$ Two hand weeding at 20 and 40 DAT, $\mathrm{T}_{4}$ : Pre-emergence herbicide followed by one hand weeding at 20 DAT, $\mathrm{T}_{5}$ : Pre-emergence herbicide followed by one hand weeding at 40 DAT, $\mathrm{T}_{6}$ : Postemergence herbicide + one hand weeding at 40 DAT, $T_{8}$ : Pre-emergence herbicide + post-emergence herbicide + one hand weeding at 40 DAT .

Table 4. Weed density (no. $\mathrm{m}^{-2}$ ) at dough stage of plant.

\begin{tabular}{|c|c|c|c|c|c|c|c|c|}
\hline \multirow{2}{*}{ Weed Species } & \multicolumn{8}{|c|}{ Treatment } \\
\hline & $T_{1}$ & $\mathrm{~T}_{2}$ & $T_{3}$ & $\mathrm{~T}_{4}$ & $T_{5}$ & $T_{6}$ & $\mathrm{~T}_{7}$ & $\mathrm{~T}_{8}$ \\
\hline Echinochloa crusgalli L. Beauv & 41.50 & 11.00 & 10.00 & 7.50 & 5.50 & 13.00 & 5.50 & 2.50 \\
\hline Scirpus juncoides Roxb. & 47.50 & 42.62 & 46.00 & 90.50 & 44.00 & 32.50 & 61.50 & 49.00 \\
\hline Monochoria hastate L. & 41.00 & 39.00 & 48.50 & 16.50 & 12.00 & 26.50 & 12.00 & 11.00 \\
\hline Cyperus esculentus L. & 0.50 & 1.00 & - & - & 0.50 & 0.50 & - & - \\
\hline Panicum repens $\mathrm{L}$. & 0.50 & 1.00 & - & - & 3.00 & 1.00 & 4.00 & 0.50 \\
\hline Leersia hexandra Sw. & 1.50 & - & - & - & 3.00 & 1.50 & 2.50 & - \\
\hline Oxalis europaea Jord. & 1.00 & - & 1.50 & - & - & 3.00 & 0.50 & 0.50 \\
\hline Parapholis incurva (L.) C. E. Hubb & 1.00 & - & - & - & - & - & - & - \\
\hline Pistia stratiotes Var. & 3.50 & - & - & 6.00 & 3.00 & - & 1.50 & 6.00 \\
\hline Digitaria sanguinalis L. & 3.50 & - & - & - & - & 0.50 & 1.00 & 1.50 \\
\hline Lippia germinata H.B.K. & - & - & 1.00 & - & - & 1.00 & 0.50 & 1.00 \\
\hline
\end{tabular}

Table 5. Weed dry weight $\left(\mathrm{g} \mathrm{m}^{-2}\right)$ at different stages.

\begin{tabular}{llll}
\hline Treatment & 20 DAT & 40 DAT & At dough stage \\
\hline $\mathrm{T}_{1}$ & - & - & 183.14 \\
$\mathrm{~T}_{2}$ & 2.35 & - & 123.48 \\
$\mathrm{~T}_{3}$ & 1.86 & 10.86 & 75.14 \\
$\mathrm{~T}_{4}$ & 2.27 & - & 91.19 \\
$\mathrm{~T}_{5}$ & - & 8.37 & 35.71 \\
$\mathrm{~T}_{6}$ & - & 9.54 & 49.56 \\
$\mathrm{~T}_{7}$ & - & - & 66.84 \\
$\mathrm{~T}_{8}$ & - & 5.53 & 34.76 \\
$\mathrm{~T}_{9}$ & - & - & - \\
\hline
\end{tabular}

Treatments: $\mathrm{T}_{1}$ : Unweeded, $\mathrm{T}_{2}$ : One hand weeding at $20 \mathrm{DAT}+$ pre-emergence herbicide after hand weeding, $\mathrm{T}_{3}:$ Two hand weeding at 20 and $40 \mathrm{DAT}$, $\mathrm{T}_{4}$ : Pre-emergence herbicide followed by one hand weeding at 20 DAT, $\mathrm{T}_{5}$ : Pre-emergence herbicide followed by one hand weeding at 40 DAT, $\mathrm{T}_{6}$ : Post-emergence herbicide + one hand weeding at 40 DAT, $T_{7}:$ Pre-emergence herbicide + post-emergence herbicide, $\mathrm{T}_{8}:$ Pre-emergence herbicide + post-emergence herbicide + one hand weeding at 40 DAT, $T_{9}:$ Weed free throughout the growth period.

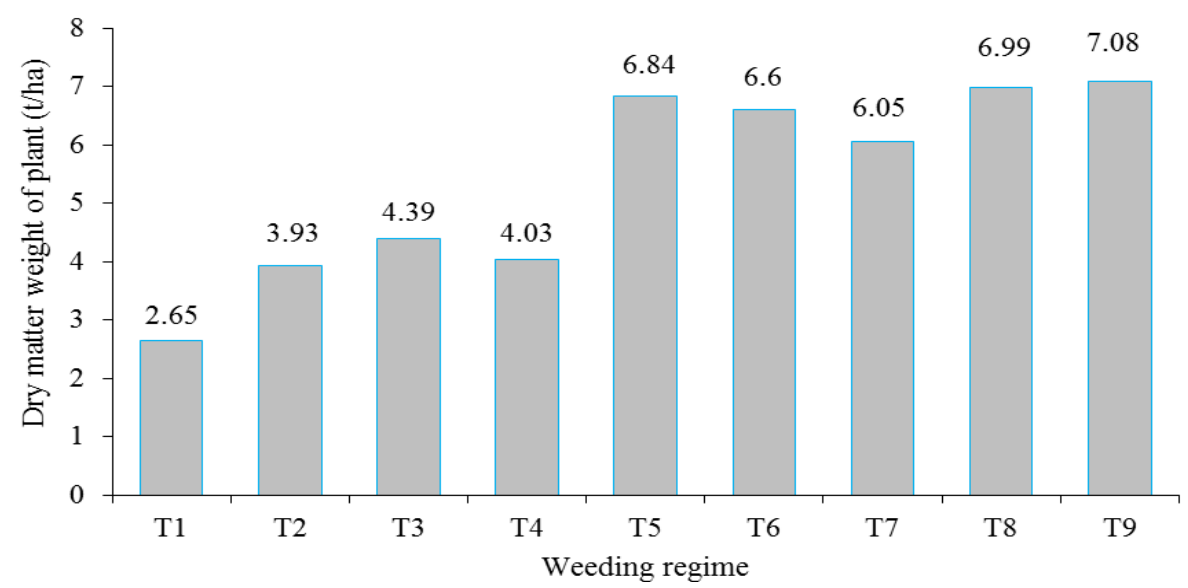

Figure 1. Effect of weeding regime on dry matter weight $\left(t h^{-1}\right)$ of plant at dough stage of aromatic Boro rice (cv. BRRI dhan50).

Treatments: $\mathrm{T}_{1}$ : Unweeded, $\mathrm{T}_{2}$ : One hand weeding at $20 \mathrm{DAT}+$ pre-emergence herbicide after hand weeding, $\mathrm{T}_{3}$ : Two hand weeding at 20 and 40 DAT, $T_{4}$ : Pre-emergence herbicide followed by one hand weeding at 20 DAT, $T_{5}$ : Pre-emergence herbicide followed by one hand weeding at 40 DAT, $\mathrm{T}_{6}$ : Post-emergence herbicide + one hand weeding at 40 DAT, $\mathrm{T}_{7}$ : Pre-emergence herbicide + post-emergence herbicide, $\mathrm{T}_{8}$ : Pre-emergence herbicide + post-emergence herbicide + one hand weeding at 40 DAT, $\mathrm{T}_{9}$ : Weed free throughout the growth period. 





Dry matter weight of plant at dough stage

The weed control treatment exerted significant effect on the dry matter weight of plant at dough stage (Figure 1). The highest dry matter weight $\left(7.08 \mathrm{t} \mathrm{ha}^{-1}\right)$ was produced by weed free throughout the growth period which was statistically identical with pre-emergence herbicide followed by one hand weeding at 40 DAT, Post-emergence herbicide + one hand weeding at 40 DAT and pre-emergence herbicide + post-emergence herbicide + one hand weeding at 40 DAT. The lowest dry matter weight $(2.65 \mathrm{t}$ $\mathrm{ha}^{-1}$ ) was obtained from unweeded treatment, which was significantly lower than the rest of the treatments. Similar results were obtained by Islam et al. (2014).

\section{Crop characters, yield components and yield}

Crop characters, yield components and yield of BRRI dhan 50 were significantly influenced by different weed control treatments have been presented in Table 6.

The highest number of tillers (10.13) was obtained in weed free throughout the growth period, which was statistically identical with two hand weeding at 20 DAT + 40 DAT, pre-emergence herbicide followed by one hand weeding at 40 DAT, postemergence herbicide + one hand weeding at 40 DAT, preemergence herbicide + post-emergence herbicide, preemergence herbicide + post-emergence herbicide + one hand weeding at 40 DAT. The lowest number of tillers (8.07) was obtained in unweeded treatment (Table 6). This result is agreement with the findings of Ahmed et al. (1998). The highest number of effective tillers hill ${ }^{-1}$ (9.19) was obtained from the plots weed free throughout the growth period, which was statistically identical with pre-emergence herbicide followed by one hand weeding at 40 DAT and pre-emergence herbicide + postemergence herbicide + one hand weeding at 40 DAT. The lowest one (5.88) was obtained in unweeded plots (Table 6). Similar results were reported elsewhere (Khan, 2013; Zannat et al., 2014; Islam et al., 2015 and Sinha et al., 2018). The highest number of non-effective tillers hill ${ }^{-1}$ (2.19) was observed in unweeded treatment, which was statistically identical with one hand weeding at 20 DAT + pre-emergence herbicide after hand weeding. The lowest number of non-effective tillers hill ${ }^{-1}$ (0.94) was observed in weed free treatment throughout the growth period (Table 6). Numerically the longest panicle was observed in weed free throughout the growth period $(21.12 \mathrm{~cm})$ and the shortest panicle was observed under unweeded treatment $(19.75 \mathrm{~cm})$ (Table 6). This result is agreement with the findings of Sinha et al. (2018). The total number of spikelets panicle ${ }^{-1}$ was the highest (99.88) in the treatment weed free throughout the growth period, which was statistically identical with pre-emergence herbicide followed by one hand weeding at 40 DAT, post-emergence herbicide + one hand weeding at 40 DAT, pre-emergence herbicide + post-emergence herbicide + one hand weeding at 40 DAT. The lowest number of spikelets panicle ${ }^{-1}(87.15)$ was produced in unweeded treatment, which was statistically identical with one hand weeding at 20 DAT + pre-emergence herbicide after hand weeding (Table 6). This result is agreement with the findings of Singh et al. (2005). The highest number of grains panicle ${ }^{-1}$
(90.41) obtained from the plots weed free throughout the growth period, which was statistically identical with pre-emergence herbicide followed by one hand weeding at 40 DAT, post-emergence herbicide + one hand weeding at $40 \mathrm{DAT}$, pre-emergence herbicide + post-emergence herbicide + one hand weeding at 40 DAT. The lowest number of grains panicle ${ }^{-1}$ (80.48) was obtained in the unweeded treatment, which was statistically identical with one hand weeding at 20 DAT + pre-emergence herbicide after hand weeding, two hand weeding at 20 DAT + 40 DAT, pre-emergence herbicide followed by one hand weeding at 20 DAT (Table 6). Similar results were reported elsewhere (Khan, 2013; Zannat et al., 2014 and Islam et al., 2015). The highest number of sterile spikelets panicle ${ }^{-1}$ (9.47) was found from weed free throughout the growth period, which was statistically identical with pre-emergence herbicide followed by one hand weeding at 40 DAT, post-emergence herbicide + one hand weeding at 40 DAT and pre-emergence herbicide + post-emergence herbicide + one hand weeding at 40 DAT. The lowest number of sterile spikelets panicle ${ }^{-1}$ (6.67) was obtained from unweeded condition period, which was statistically identical with one hand weeding at 20 DAT + preemergence herbicide after hand weeding and pre-emergence herbicide followed by one hand weeding at 20 DAT (Table 6). The highest 1000 grain weight $(19.51 \mathrm{~g})$ was found from weed free throughout the growth period, which was statistically identical with pre-emergence herbicide followed by one hand weeding at 40 DAT, post-emergence herbicide + one hand weeding at 40 DAT and pre-emergence herbicide + post-emergence herbicide + one hand weeding at 40 DAT. The lowest $1000^{-}$grain weight (17.97 g) was obtained from unweeded treatment, which was statistically identical with one hand weeding at 20 DAT + pre-emergence herbicide after hand weeding (Table 6). This result is agreement with the findings of Ganeshwor and Gadadhar (2000). Among the weed control treatments, the highest grain yield (5.92 $\mathrm{t} \mathrm{ha}^{-1}$ ) was produced by weed free throughout the growth period followed by pre-emergence herbicide + post-emergence herbicide + one hand weeding at 40 DAT $\left(5.46 \mathrm{t} \mathrm{ha}^{-1}\right)$. The lowest grain yield $\left(2.58 \mathrm{t} \mathrm{ha}^{-1}\right)$ was obtained from unweeded treatment, which was significantly lower than the rest of the treatments. Grain yield reduced by $56.42 \%$ in control (unweeded) plots over weed free throughout the growth period (Table 6). This result is agreement with the findings of Sinha et al. (2018), who reported that weed infestation reduced drastically reduced grain yield by $59.82 \%$ in BRRI dhan50. The highest straw yield $\left(7.13 \mathrm{t} \mathrm{ha}^{-1}\right)$ was found from weed free throughout the growth period followed by preemergence herbicide + post-emergence herbicide + one hand weeding at 40 DAT $\left(6.68 \mathrm{t} \mathrm{ha}^{-1}\right)$ and this two treatments were statistically identical. The lowest straw yield $\left(3.87 \mathrm{t} \mathrm{ha}^{-1}\right)$ was obtained from no weeding condition (Table 6). This result is agreement with the findings of Sinha et al. (2018). The highest biological yield (13.06 $\mathrm{t} \mathrm{ha}^{-1}$ ) was found from weed free throughout the growth period followed by pre-emergence herbicide + post-emergence herbicide + one hand weeding at 40 DAT $\left(12.15 \mathrm{t} \mathrm{ha}^{-1}\right)$. The lowest biological yield $\left(6.45 \mathrm{t} \mathrm{ha}^{-1}\right)$ was 
obtained from no weeding condition (Table 6). The highest harvest index (45.33\%) was found in weed free throughout the growth period, which was statistically identical with preemergence herbicide followed by one hand weeding at 40 DAT and pre-emergence herbicide + post-emergence herbicide + one hand weeding at 40 DAT. The lowest harvest index (40.00\%) was found from no weeding treatment (Table 6). Similar results were obtained by Zannat et al. (2014) and Islam et al. (2015). The highest benefit cost ratio (2.28) was obtained from pre-emergence herbicide + post-emergence herbicide + one hand weeding at 40 DAT.

Relationship between dry matter weight of plants and grain yield

Relationship between dry matter weight of plants and grain yield was shown in the graph (Figure 2). Dry matter weight of plants was recorded in dough stage of the plant. A significant relationship was observed in grain yield and dry matter weight of plants. Grain yield increases progressively with the increase in dry matter weight of plant could be adequately described by regression equation $Y=0.6907 x+0.5624\left(R^{2}=0.974\right)$. The functional relationship indicates that $97 \%$ of the variation in grain yield could be explained from the variation in matter production of plant at dough stage. Similar result was reported by Ray et al. (2015)

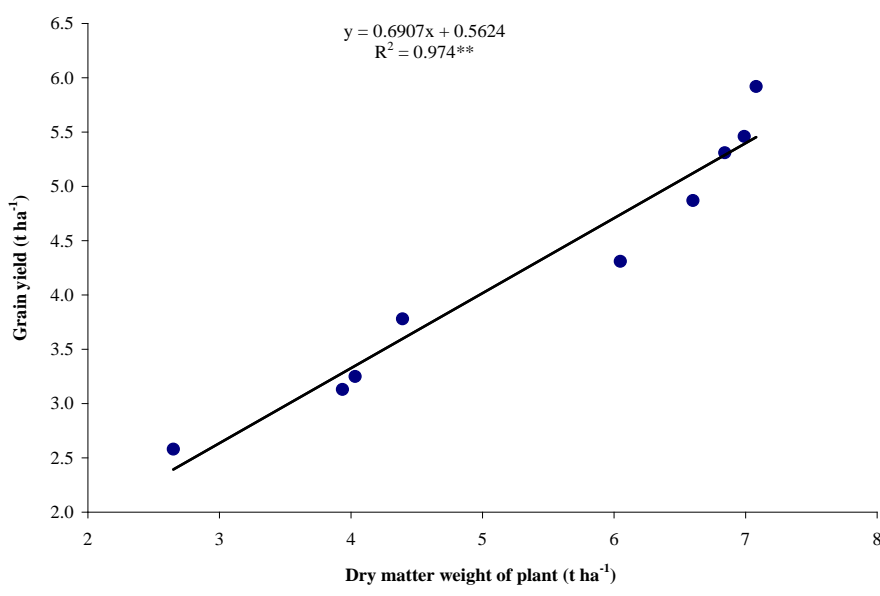

Figure 2. Relationship between dry matter weight of plants at dough stage and grain yield of aromatic Boro rice (cv. BRRI dhan50).

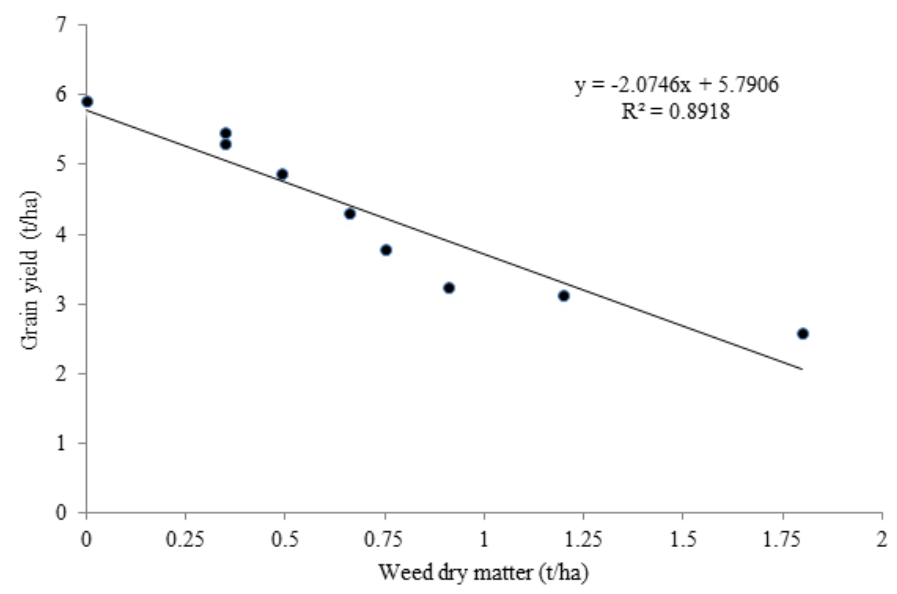

Figure 3. Relationship between dry matter weight of weeds at dough stage and grain yield of aromatic Boro rice (cv. BRRI dhan50).
Relationship between dry matter weight of weeds and grain yield

Relationship between dry matter weight of weeds and grain yield was shown in the graph (Figure 3). A reciprocal relationship was observed between dry matter weight of weeds at dough stage and grain yield of Boro rice. Dry matter weight of weeds was recorded at 20 DAT, 40 DAT and dough stage of the plant. Grain yield decreased due to increase in dry matter weight of weeds. The response of weed dry matter production to the grain yield of rice followed a linear negative relationship which could be adequately described by regression equation $Y=$ $-2.0746 x+5.7906\left(R^{2}=0.8918\right)$. The functional relationship indicates that $89 \%$ of the variation in grain yield could be explained from the variation in weed dry matter production at dough stage. This finding is in agreement with that of Sinha et al. (2018) who reported that $89 \%$ of Boro rice (cv. BRRI dhan50) yield could be explained by the functional relationship of weed dry matter production at 65 DAT while Islam et al. (2015) reported that $80 \%$ of the variation in grain yield could be explained from the variation in weed dry matter production at 60 DAT in BRRI dhan49

\section{Conclusion}

Weeding regime has significant influence on yield and yield contributing characters of aromatic rice. The tallest plant, the highest number of total tillers hill ${ }^{-1}$, number of effective tillers hill $^{-1}$, grains panicle ${ }^{-1}, 1000^{-}$grain weight, grain yield and straw yields were obtained from weed free treatment. From the present study it can be concluded that weed free throughout the growth period had pronounced influence on yield of aromatic Boro rice followed by pre-emergence herbicide + post-emergence herbicide + one hand weeding at 40 DAT. However, the highest benefit cost ratio was obtained from pre-emergence herbicide + post-emergence herbicide + one hand weeding at 40 DAT. Therefore, application of pre-emergence herbicide (Panida @ $2.5 \mathrm{~L} \mathrm{ha}^{-1}$ ) followed by post-emergence herbicide (Granite@ $93.70 \mathrm{ml} \mathrm{ha}^{-1}$ ) + one hand weeding at 40 DAT appears as the promising technique for controlling weeds in aromatic Boro rice (cv. BRRI dhan50) cultivation in Bangladesh.

\section{ACKNOWLEDGEMENTS}

The financial assistance of the Ministry of Science and Technology, Govt. of the People's Republic of Bangladesh to carry out the research work is thankfully acknowledged.

Open Access: This is an open access article distributed under the terms of the Creative Commons Attribution 4.0 License, which permits unrestricted use, distribution, and reproduction in any medium, provided the original author(s) if the sources are credited. 


\section{REFERENCES}

Ahmed, G.J.U., Bhuiyan, M.K.A., Riches, C.R., Mortimer, M. and Jhonson, D. (2005). Farmer's participatory studies of integrated weed management system for intensified low land. Proceeding of the 8th Biennial Agronomy Convention, Bangladesh Agronomy Journal, 23: 31-32.

Ahmed, Z., Khan, D.R., Alim, S.D., Tahir, M. and Marwat, K.B. (1998). Effect of economics of time and weeds removal on the yield and yield components of rice. Sarhad Journal of Agriculture, 14(4): 335-338.

Ganeshwor, T. and Godadhar, M. (2000). Effectiveness of herbicides on controlling weed sin transplanted rice. Nio-Botanica, 8(1/2): 1-6.

Gomez, M.A. and Gomez, A.A. (1984): Statistical procedures for Agricultural Research. John wiley and sons. New York, Chichesten, Brisbane, Torobto. pp. 97-129, 207-215.

Islam, M., Rafiqul, B.A.A., Mustafi, S. and Hossain, M. (1996). Socio-economic aspects of fine quality rice cultivation in Simulation of Yield Losses Caused by Rice Diseases, Insects, and Weeds in Tropical Asia. IRRI Discussion Paper Series No. 34. pp. 18-20.

Islam, S.M.M., Paul, S.K. and Sarkar, M.A.R. (2015). Effect of weeding regime and integrated nutrient management on yield contributing characters and yield of BRRI dhan49. Journal of Crop and Weed, 11: 193-197.

Islam, S.M.M., Paul, S.K., Sarkar, M.A.R. and Miah, M.A.M. (2014). Effect of weeding regime and integrated nutrient management on growth and yield of transplant Aman rice (cv. BRRI Dhan49). Bangladesh Journal of Progressive Science and Technology, 12(1): 049-054.

Jena, S.N., Tripathy, S., Sarangi, S.K. and Biswal, S. (2002). Integrated weed management in direct seeded rainfed lowland rice. Indian Journal of Weed Science, 34(1-2): 32-35.

Kabir, M.E., Kabir, M.R., Jahan, M.S. and Das, G.G. (2004). Yield performance of three aromatic fine rices in a coastal medium high land. Asian Journal of Plant Sciences, 3: 561-563.
Khan, K.Z. (2013). Influence of plant spacing and weeding regime on the performance of transplant Aman rice cv. BINA Dhan 7. M.S. Thesis, Department of Agronomy, Bangladesh Agricultural University, Mymensingh. Bangladesh.

Ray, S., Sarkar, M.A.R., Paul, S.K., Islam, A.K.M.M. and Yeasmin, S. (2015). Variation of growth, yield and protein content of transplant Amanrice by three agronomic practices. Agricultural and Biological Sciences Journal, 1(4): 167-176.

Rekha, K.B., Razu, M.S. and Reddy, M.D. (2002). Effect of herbicides in transplanted rice. Indian Journal of Weed Science, 34(1-2): 123-125.

Roy, A., Sarkar, M.A.R. and Paul, S.K. (2018). Effect of age of seedlings at staggered transplanting and nutrient management on yield performance of aromatic fine rice (cv. BRRI dhan38). SAARC Journal of Agriculture, 16(1):49-59.

Sarkar, M.A.R., Paul, S.K. and Paul, U. (2017). Effect of water and weed management in Boro rice (cv. BRRI dhan28) in Bangladesh. Archives of Agriculture and Environmental Science, 2(4): 325-329, https://doi.org/10.26832/24566632.2017.020414

Sathyamoorthy, N.K., Mahhendran, S., Babu, R. and Ragavan, T. (2004). Effect of integrated weed management practices on total weed dry weight, nutrient removal of weeds in rice-rice wet seedbed system. Journal of Agronomy, 3(4): 263-267.

Singh, G., Singh, R.G., Singh, O.P., Kumar, T., Metha, R.K. and Singh, P.P. (2005). Effect of weed management practices on transplanted rice. Indian Journal of Agronomy, 50(1): 25-37.

Sinha, T., Paul, S.K. and Sarkar, M.A.R. (2018). Effect of age of seedlings at staggered transplanting and weed management on the growth and yield of aromatic Boro rice (cv. BRRI dhan50). Journal of the Bangladesh Agricultural University, 16(1): 5-11.

Zannat, S.T., Paul, S.K. and Salam, M.A. (2014). Effect of weeding regime and nitrogen management on the performance of transplant aromatic Aman rice (cv. Binadhan-9). Bangladesh Journal of Seed Science \& Technology, 18 (1\& 2): 29-34. 